Reprod. Nutr. Dévelop., 1981, 21 (6B), 1043-1048.

\title{
Sperm number required for maximum fertility of chicken semen processed for freezing
}

\author{
by T. J. SEXTON
}

\author{
U.S. Department of Agriculture, SEA-AR \\ Avian Physiology Laboratory, Beltsville, Maryland 20705, U.S.A.
}

Summary. Two independent experiments were designed to determine the number of sperm needed for maximum fertility of chicken semen processed for freezing. Pooled semen samples were either diluted 1:2 or 1:5 with the Beltsville Poultry Semen Extender, while undiluted samples served as controls. Samples were then subsequently processed (prefreeze), according to the Beltsville method, as if they were going to be frozen. At two stages of processing, after 2-hr holding at $5^{\circ} \mathrm{C}$ in the absence of dimethylsulfoxide (DMSO) and after an additional 2-hr holding at $5{ }^{\circ} \mathrm{C}$ in the presence of $4 \mathrm{p} .100 \mathrm{DMSO}$, aliquots were removed and tested for fertility. Each test hen was intravaginally inseminated with either 100,300 , or 600 million sperm from undiluted or processed semen samples. The number of sperm required for the undiluted controls was determined to be 100 million sperm whereas the fertility of samples processed with 4 p. 100 DMSO was significantly lower than the undiluted controls regardless of the sperm number inseminated or the dilution rate. Dilution rate did influence the number of sperm required for samples cooled for $2 \mathrm{hrs}$ at $5 \mathrm{o}^{\circ} \mathrm{C}$ in the absence of DMSO. In samples diluted 1:2,100 million sperm were needed for maximum fertility, whereas 300 million sperm were needed with samples diluted 1:5.

\section{Introduction.}

Considerable research has been devoted to the problem of poultry semen storage ; see reviews by Lorenz (1969) and Sexton (1979). The potential advantages of long-term preservation of poultry semen by freezing have long been recognized by researchers and breeders. Several semen freezing techniques have been reported that differ with respect to diluents, cryoprotectants, freezing methods, etc. (Sexton, 1976 ; Watanabe and Terada, 1977 ; Lada-Gorzowska ef al., 1978 ; Lake and Stewart, 1978).

In studies involving the fertility of processed unfrozen semen, or frozen-thawed, it is desirable to know the minimum number of sperm (MNS) required per insemination dose that will yield maximum fertility. The MNS required for undiluted fresh semen (e.g. Kim ef al., 1974) and frozen-thawed (Sexton, 1976) has been determined to be 50 and 300 million sperm/dose, respectively. These data indicate that sperm are being damaged by freezing and thawing, but offer little indication if sperm are being damaged during processing for freezing. The purpose of this study was to determine the number of sperm needed for maximum fertility of semen removed at various prefreeze steps of the Beltsville method for freezing chicken semen. 


\section{Materials and methods.}

Evaluation of semen. - Semen was collected from mature meat-type male chickens that had not been previously selected for any reproductive traits. Twenty males were housed in individual cages and maintained on a routine semen collection schedule of two times per week. Care was taken to minimize contamination of the semen by feces or urates. Semen, pooled from at least 5 males, was collected into conical glass centrifuge tubes $(17 \times 119 \mathrm{~mm})$ maintained at $25^{\circ} \mathrm{C}$. Successive semen pools did not necessarily contain semen samples from the same males. Semen qualify was assessed by estimating progressive motility and determining sperm concentration on each undiluted sample or within $5 \mathrm{~min}$ after dilution on a diluted sample. Progressive motility was scored on a scale from 0 to 100 using phase contrast microscopy at $430 X$ magnification on a microscope slide maintained at $25^{\circ} \mathrm{C}$. An aliquot $(10 \mu \mathrm{l})$ of semen was removed and further diluted to $10 \mathrm{ml}$ with $3 \mathrm{p} .100 \mathrm{NaCl}$, and the sperm cell concentration was determined with a Klett-Summerson $\left({ }^{1}\right)$ photometer at 400-465 m $\mu$. Sperm concentration was estimated from a standard curve which was developed by comparing optical density with hemocytometer sperm counts.

Processing procedure. - Two independent experiments were designed to determine the minimum number of processed (pre-freeze) unfrozen sperm needed for maximum fertility. In experiment \#1, the pooled sample was divided into 2 equal parts and diluted 0 or 1:2 with BPSE. In experiment \#2, the pooled sample was divided into 2 equal parts and diluted 0 or 1:5. The diluted semen samples in both experiments were further processed (Steps 3 to 5) as outlined in table 1. The rationale for the selection of each of the processing steps was based on previously published data (table 1).

TABLE 1

Processing Procedure

\begin{tabular}{cccc}
\hline Step \# & Treatment & Procedure & Reference \\
\hline 1 & Diluent & Beltsville Poultry Extender ${ }^{*}$ & Sexton, 1977 \\
2 & Semen : diluent & $1: 5^{\circ}$ & Sexton, 1980 \\
3 & Cooling & $2 \mathrm{hr}$ at $5{ }^{\circ} \mathrm{C}$ & Sexton, 1980 \\
4 & Cryoprotectant & $4 \mathrm{p.} 100^{\mathrm{DMSO}}$ & Sexton, 1973, 1975 \\
5 & Equilibration & $2 \mathrm{hr}$ at $5{ }^{\circ} \mathrm{C}$ & Sexton, 1980 \\
\hline
\end{tabular}

* Composition of the Beltsville Poultry Semen Extender was described by Sexton (1977).

Fertility assessment. - One hundred and eighty dwarf broiler breeders were randomly divided to ten hens per treatment. Each hen was intravaginally inseminated with either 100, 300 or 600 million sperm from undiluted controls or samples processed to either Step 3 or 5, table 1. Each hen was inseminated weekly for 5 consecutive weeks.

(1) Mention of a trade name, proprietary product, or specific equipment does not constifute a guarantee or warranty by the US Department of Agriculture and does not imply its approval to the exclusion of other products that may be suitable. 
Eggs were collected daily, held at $15^{\circ} \mathrm{C}$ and incubated within 7 days. Fertility was estimated on approximately 184 eggs/treatment by candling on Day 7 of incubation and was expressed as the percentage of viable embryos.

Statistical analyses. - All experiments were designed as randomized complete blocks and insemination week was used as a block. Percentage data were transformed to arcsin, and significance was determined at the 5 p. 100 level of probability by analysis of variance (AOV). Differences between treatment means were estimated by the Least Significant Difference Test (LSD). Means and standard errors of the mean (SEM) were calculated from nontransformed dafa for each treatment group from separate analyses within each group.

\section{Results and discussion.}

In assessing the fertility of a semen sample that was previously treated in vitro, it is important to be able to distinguish the treatment effect from non-treatment effect. The most frequent non-treatment effect encountered in the use of artificial insemination is the insemination of too few numbers of sperm. This problem becomes critical in studies designed to measure the effect of a semen treatment on fertility because of the inability to separate treatment effects from the effect of low sperm numbers inseminated.

A minimum of 50 to 100 million sperm per weekly insemination is needed for maximum fertility levels with undiluted semen (Taneja and Gowe, 1962 ; Kim et al., 1974 ; Sexton, 1976). The results reported in tables 2 and 3 concur that a dose of 100 million sperm was adequate to achieve maximum fertility. Increasing the insemination dose of undiluted semen from 100 to 300 or 600 million sperm did not increase fertility levels.

Several investigators have attempted to determine the MNS required per dose of semen diluted in a variety of extenders. The results reported for MNS ranged from 45 to 90 million sperm (Cooper and Rowell, 1958 ; Rowell and Cooper, 1960 ; Kim ef al., 1974). The range of values could be attributed to certain experimental design factors such as the extender used, dilution rate and the semen holding conditions (time and temperature). In the present study two dilution rates $(1: 2$ and $1: 5)$ were studied along with two holding conditions (held at $5^{\circ} \mathrm{C}$ for $2 \mathrm{hr}$, followed by the addition of $4 \mathrm{p} .100$

TABLE 2

Relationship of number of sperm inseminated to the percent fertility of semen diluted $1: 2$ and processed for freezing $\left({ }^{1}\right)$

\begin{tabular}{|c|c|c|c|c|}
\hline \multicolumn{2}{|r|}{ Processing Procedure } & \multicolumn{3}{|c|}{ Insemination dose of $\left(\times 10^{6}\right)$} \\
\hline Step $\left({ }^{2}\right)$ & Treatment & 100 & 300 & 600 \\
\hline $\begin{array}{l}-3 \\
5\end{array}$ & 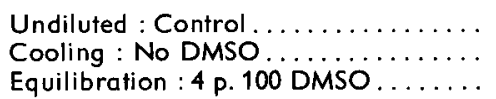 & $\begin{array}{l}91 \pm 2\left({ }^{a}\right) \\
86 \pm 4\left({ }^{a, b}\right) \\
81 \pm 3\left({ }^{b, d}\right)\end{array}$ & $\begin{array}{l}90 \pm 2\left({ }^{a}\right) \\
93 \pm 1\left({ }^{a}\right) \\
77 \pm 7\left({ }^{b, d}\right)\end{array}$ & $\begin{array}{l}95 \pm 1\left({ }^{a}\right) \\
88 \pm 4\left({ }^{a, b, c}\right) \\
82 \pm 4\left({ }^{b, c, d}\right)\end{array}$ \\
\hline
\end{tabular}

( $\left.{ }^{1}\right)$ Mean and SEM of 5 weekly inseminations. $\left({ }^{2}\right)$ See Table 1.

$(a, b, c)$ Means having different superscripts within columns are significantly different $(P<0.05)$.

$\left({ }^{a, d}\right)$ Means having different superscripts within rows are significantly different $(P<0.05)$. 
DMSO and held an additional $2 \mathrm{hr}$ ). These processing procedures are normally used in the Beltsville technique for freezing and thawing chicken semen (Sexton, 1980).

The fertility of semen samples diluted $1: 2$ then held at $5{ }^{\circ} \mathrm{C}$ for $2 \mathrm{hr}$ was no different than the undiluted controls (table 2 ) regardless of the number of sperm $(100,300$ or 600 million) per insemination dose. This agrees with an earlier report by Sexton (1977) which indicated that the fertility of diluted $(1: 2)$ chicken semen held 30 min at $5{ }^{\circ} \mathrm{C}$ was unaffected by weekly insemination doses containing 20, 50 or 100 million sperm. Sexton (1977) also indicated that increasing the holding temperature from $5 \circ$ to $25{ }^{\circ} \mathrm{C}$ resulted in lowered fertility with weekly insemination doses of 20 or less million sperm.
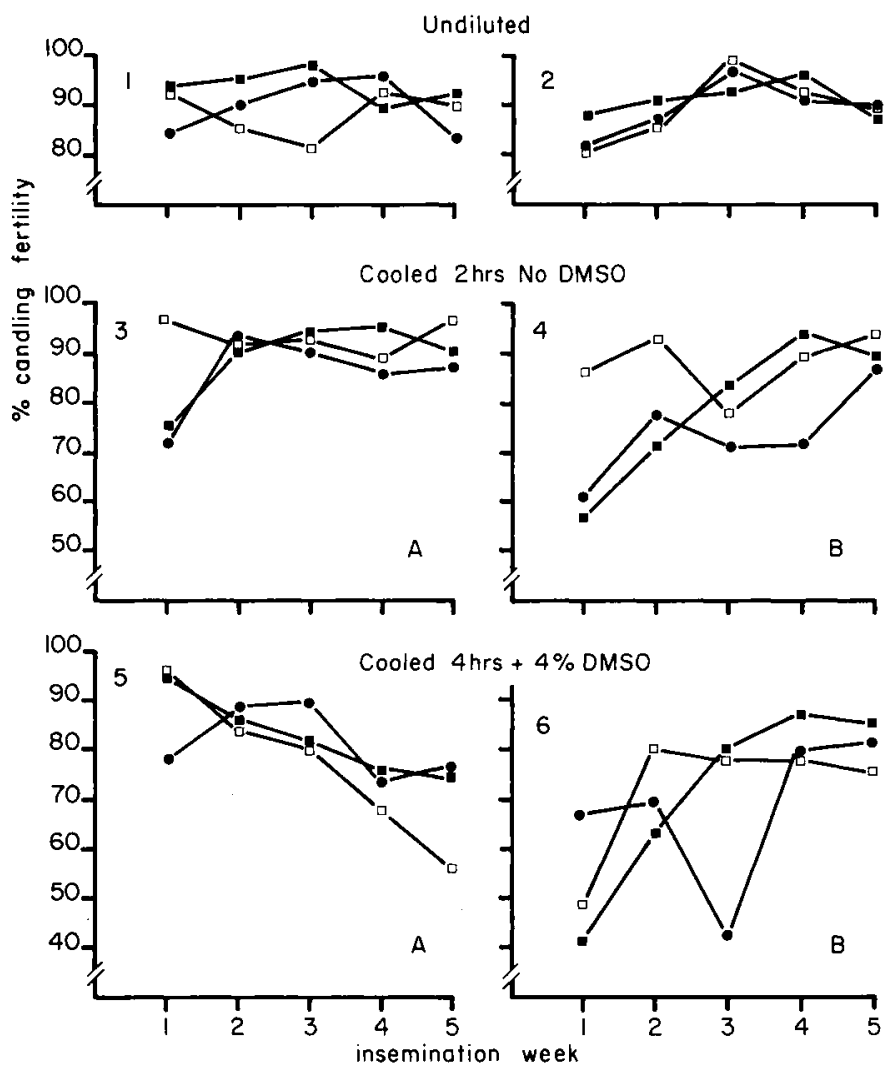

FIG. 1. - Fertility of hens inseminated weekly with $100(\bullet-\bullet), 300(\square-\square)$ or $600(\square-\square)$ million sperm previously diluted 1:2 (A) or 1:5 (B), processed buf not frozen.

These data clearly illustrate that diluting and/or processing semen could alter the number of sperm required per insemination dose. A very good example of this can be seen from the data reported in tables 2 and 3 on holding sperm at $5^{\circ} \mathrm{C}$ for $2 \mathrm{hr}$. Although 100 million sperm per weekly insemination were needed for a sample diluted $1: 2$ (table 2), inseminating hens with a similar number of sperm diluted $1: 5$ and similarly treated resulted in lowering fertility below the level of the undiluted control 
TABLE 3

Relationship of number of sperm inseminated to the percent fertility of semen diluted $1: 5$ and processed for freezing $\left({ }^{1}\right)$

\begin{tabular}{|c|c|c|c|c|}
\hline \multicolumn{2}{|r|}{ Processing Procedure } & \multicolumn{3}{|c|}{ Insemination dose of $\left(\times 10^{6}\right)$} \\
\hline Step $\left({ }^{2}\right)$ & Treatment & 100 & 300 & 600 \\
\hline $\begin{array}{l}1 \\
3 \\
5\end{array}$ & $\begin{array}{l}\text { Undiluted : Control ................ } \\
\text { Cooling : No DMSO } \ldots \ldots \ldots \ldots \ldots \\
\text { Equilibration : } 4 \text { p. } 100 \text { DMSO } \ldots \ldots\end{array}$ & $\begin{array}{l}89 \pm 2\left({ }^{a, c}\right) \\
74 \pm 4\left({ }^{b, c}\right) \\
64 \pm 5\left({ }^{b, c}\right)\end{array}$ & $\begin{array}{l}92 \pm 4\left({ }^{a, c}\right) \\
87 \pm 3\left({ }^{a, c}\right) \\
72 \pm 6\left({ }^{b, c}\right)\end{array}$ & $\begin{array}{l}91 \pm 1\left(^{a, c}\right) \\
80 \pm 7\left({ }^{a, c}\right) \\
71 \pm 8\left(^{(b, c)}\right.\end{array}$ \\
\hline
\end{tabular}

( $\left.{ }^{1}\right)$ Mean and SEM of 5 weekly inseminations. $\left({ }^{2}\right)$ See Table 1.

$\left({ }^{a, b}\right)$ Means having different superscripts within columns are significantly different $(P<0.05)$.

$\left({ }^{c, d}\right)$ Means having different superscripts within rows are significantly different $(P<0.05)$.

(table 3). An insemination dose of 300 million sperm was needed for maximum fertility of semen samples diluted $1: 5$ and held at $5{ }^{\circ} \mathrm{C}$. Chicken semen diluted and held at $5{ }^{\circ} \mathrm{C}$ for up to 24 hrs did not show a loss in fertility (Van Wambeke, 1968 ; Sexton, 1978). Thus, it appears that dilution rate is crucial for semen samples subsequently stored at low temperatures and that the limits for dilution appear to be extremely narrow.

Dimethylsulfoxide (DMSO) as well as other cryoprotective compounds have been used in media for freezing and thawing of poultry spermatozoa. Unfortunately when used at concenfrations necessary for cryoprotection, these compounds reduce the fertilizing capacity of sperm (Sexton, 1973 ; Schramm, 1976). The data reported in tables 2 and 3 indicate that DMSO significantly reduced fertility. Increasing the insemination dose from 100 to 600 million sperm did not improve the fertility. Although no direct comparisons can be made between the data in tables 2 and 3 because the data were obtained from two independent studies, it appears that the DMSO effect on fertility was greater in samples diluted 1:5 than those samples diluted 1:2.

Although 4 p. 100 DMSO significantly reduced fertility after equilibration, further processing (freezing and thawing) has resulted in candling fertility levels of 61 to 67 p. 100 (Sexton, 1976), with the use of frozen semen under field conditions and such fertility levels can be maintained with samples stored for 56 weeks in liquid nitrogen (Sexton, 1980). As a result, several companies are using the Beltsville Method for freezing semen and using frozen semen in their pedigree breeding programs.

Workshop on «Avian male reproduction 》 Nouzilly, France, June 1980.

Acknowledgement. - The author wishes to express appreciation to D. M. Gavelek for her technical assistance.

Résumé. Deux expériences indépendantes ont été organisées pour déterminer le nombre de spermatozoïdes nécessaire à l'obtention d'une fertilité maximum avec du sperme de coq préparé pour la congélation. Des échantillons provenant de mélanges de sperme ont été dilués $1: 2$ ou 1:5 avec le dilueur de Beltsville, avec comme témoins des échantillor.s non dilués. Ces échantillons ont été traités suivant le protocole de précongélation utilisé à Beltsville, comme s'ils devaient réellement être congelés. A deux étapes de cette préparation 
des spermes, c'est-à-dire après maintien $2 \mathrm{~h}$ à $5^{\circ} \mathrm{C}$ en l'absence de DMSO, et après $2 \mathrm{~h}$ supplémentaires à $5{ }^{\circ} \mathrm{C}$ en présence de DMSO à 4 p. 100, des aliquots ont été testées pour la fécondance. Chaque poule a été inséminée par voie intravaginale avec 100, 300 ou 600 millions de spermatozoïdes venant de sperme non dilué, ou préparé pour la congélation. Le nombre de spermatozoïdes nécessaires pour une fertilité optimum était de 100 millions avec les spermes non dilué, alors que la fertilité obtenue avec le sperme en présence de 4 p. 100 de DMSO était significativement plus faible que celle des témoins quels que soient les nombres de spermatozoïdes inséminés et les taux de dilution. Le nombre de spermatozoïdes nécessaires à l'obtention d'une fertilité optimum a été influencé par le taux de dilution des échantillons stockés à $5^{\circ} \mathrm{C}$ pendant $2 \mathrm{~h}$ sans DMSO : avec le taux de dilution $1: 2$ ce nombre éłait de 100 millions alors qu'il était de 300 millions avec le sperme dilué à 1:5.

\section{References}

COOPER D. M., ROWELL J. G., 1958. Relations between fertility, embryonic survival and some semen characteristics in the chicken. Poultry Sci., 37, 699-707.

KIM J. K., SHIN W. J., SHUS G. S., SUL D. S., LEE J. K., 1974. Effect of dilution rate of semen and insemination interval on fertility in the domestic fowl. Res. Report, Office Rural Develop. Suwon, Korea, 77-81.

LADA-GORZOWSKA A., KRAWCZYK E., FIMA D., WATANABE M., 1978. Freezing of fowl semen. J. Fac. Fish. anim. Husb., 17, 143-146.

LAKE P. E., STEWART J. M., 1978. Preservation of fowl semen in liquid nitrogen. An improved method. Br. Poultry Sci., 19, 187-194.

LORENZ F.W., 1969. In Reproduction in domestic animals, H. H. COLE, P. T. CUPPS, 1st ed., Acad. Press, New York.

ROWELL J. C., COOPER D. M., 1960. Some effects of diluting cock semen. Poultry Sci., 39, 1381-1389.

SCHRAMM G. P., 1976. Action of cryoprotectives glycerin, ethylene glycol, and dimethylsulphoxide on fertilisation potential of cock semen. Monatsh. Meterinaermed., 20, 770-773.

SEXTON T. J., 1973. Effect of various cryoprotective agents on the viability and reproductive efficiency of chicken spermatozoa. Poultry Sci., 52, 1353-1357.

SEXTON T. J., 1975. Relationship of the method of addition and temperature of cryoprotective agents to the fertilizing capacity of cooled chicken spermatozoa. Poultry Sci., 54, 845-848.

SEXTON T. J., 1976. Studies on the fertility of frozen fowl semen 8th int. Congr. anim. Reprod. Artif. Insem., Cracow, 4, 1079-1082.

SEXTON T. J., 1977. A new poultry semen extender. I. Effect of extension on the fertility of chicken semen. Poultry Sci., 56, 1443-1446.

SEXTON T. J., 1978. A new poultry semen extender. III. Effect of storage conditions on the fertilizing capacity of chicken semen stored at $5^{\circ} \mathrm{C}$. Poultry Sci., 57, 285-289.

SEXTON T. J., 1979. Preservation of poultry semen. A Review, Symp. Beltsville Symposia in Agricultural Research 3. Animal Reproduction, Allanheld, Osmum \& Co. Publ., Montclair, N. J.

SEXTON T. J., 1980. Recent advances in semen storage of the fowl and turkey. 9th int. Congr. anim. Reprod. Artif. Insem., Madrid, 2, 527-533.

WATANABE M., TERADA T., 1977. A diluent for deep freezing preservation of fowl spermatozoa. J. Fac. Fish. anim. Husb., 16, 59-64.

TANEJA G. C., GOWE R. S., 1962. Effect of varying doses of undiluted semen of fertility and hatchability in the domestic fowl. Anim. Breed. Abstr., 35, 1592.

VAN WAMBEKE F., 1968. The effect of an oxygenated storage medium on the fertilizing capacity of fowl spermatozoa stored for different periods. 8th int. Congr. anim. Reprod. Art. Insem., Paris, 2, 1645-1647. 